\title{
The role of improving the teaching quality for students' evaluation on higher vocational college teachers
}

\author{
Hu Yanni,Huang Bo,Zhao Lei, Zheng Huan ${ }^{* a}$ \\ Wuhan Institute of Shipbuilding Technology, Wuhan 430050, China \\ awist_777@qq.com
}

\begin{abstract}
Keywords:student teaching evaluation ; teachīng quality; excellent teacher; CLEMENTINEA; quality training
\end{abstract}

Abstract. Students' evaluation of teaching is an important way to improve the teaching quality of teachers in Colleges and universities. The paper established the scientific rating system through the evaluation of teaching data mining, and it constantly sum up experience to promote teachers' training quality,which has an important role and significance. In this paper, it introduced the scientific and efficient design evaluation teaching process and index through the precise positioning of Students' evaluation of teaching. Then it used the data mining software CLEMENTINEA to evaluate data for processing and analysis. It summed up the outstanding teachers and bad review the important quality characteristics of teachers from a full range of teachers' teaching effect diagnosis, such as teachers' professional morality, teaching organization and to grasp the classroom effect, enrich and update teaching content of teachers most popular with students. At the same time, these data and conclusions for the school's teaching management department can provide help for teachers' training, and it is conducive to the formation of a good quality of teacher training strategies for similar colleges and universities, which provides a reference for teacher training.

\section{Introduction}

The quality of teachers and teaching quality are essential for the survival and development of colleges and universities. The university teachers are very important resources. In order to train more outstanding talents, it is imperative to improve the quality of teaching. Because the objective judgment on the quality of teachers' teaching, teaching quality monitoring is an important way. Therefore, teacher evaluation teaching mode and strategy is fair, fair, reasonable and effective, has become the focus of public concern. At present, the evaluation of teaching mainly including students, observers and the two colleges and other evaluation methods, in these four ways of teaching, the most intuitive and effective. To carry out students' evaluation of teaching activities can not only promote the improvement of teaching quality, strengthen the interaction between teachers and students, enhance the sense of responsibility, but also improve the quality of teachers' morality accomplishment and teaching.

\section{The precise positioning of students' evaluation of teaching}

Students evaluation is an important way to improve the teaching quality of college teachers, if only a simple evaluation of the students to achieve the assessment and management of teachers, it will bring the results of the opposite. In order to make the students evaluation in the assessment and management of teachers play a more important role, first of all, it should be accurate positioning of students' assessment of teaching.

\section{The positioning the Students' evaluation of teaching function}

The main function of the evaluation of teaching is to realize the teacher evaluation and promote the teaching reform, therefore, students' evaluation of teaching needs to achieve these two points, rather than just for the teacher assessment. From two aspects of theory and reality, students' evaluation of teaching can achieve two functions of teacher evaluation and promoting teaching reform.

First, from the realistic in terms of, even the teacher development as the purpose of the evaluation, evaluation of teaching also has a role in improving the quality of teachers, teachers' teaching quality can improve in time and time again in the evaluation of, just in this evaluation system, teacher 
development and progress does not as the purpose of the evaluation, but derived to a "by-product". Therefore, the teachers' development as the purpose of the evaluation, will be able to more system to improve the teaching quality of teachers and professional development of teachers; secondly, in terms of theory, to raise the quality of teaching as the purpose of the evaluation, teachers will make greater progress.

\section{The Students' evaluation of teaching goal orientation}

Students' evaluation of teaching aims is to improve the teaching quality and to improve the utilization of resources, so as to achieve the optimization of teaching links. Whether it is from the school, or teachers and students, they can be the goal of unity, the unity of the three goals to promote the quality of teaching. Starting from the point of view of teachers, students' evaluation of teaching this activity is actually between teachers and students to communicate as a means, the teacher can by means of evaluation of teaching students to understand the ideas and requirements, which helps to reduce the conflicts between teachers and students, more conducive to the improvement of teaching method and optimization. At the same time, teachers pay more attention to the students' inner thoughts, solicit the opinions of the students, improve the teaching quality and improve the teaching quality. Starting from this perspective can not only reduce the contradiction between teachers and students, to ease tensions between teachers and students, let the students feel the teacher that seriously and responsible and more objective were evaluation of teaching activities, the teaching evaluation result more real and effective.

\section{The scientific and efficient design and evaluation of teaching process and indicators}

Students' evaluation of teaching is students according to the teacher's teaching attitude, teaching methods, teaching content, teaching effect, performance in class and their learning experience and harvest evaluation of teachers, in order to make students more objectively and accurately evaluate the teaching quality, while promoting the interaction between teachers and students, we need to efficiently design teaching evaluation index. Students' evaluation of teaching process as shown in Figure 1.

\section{Multi evaluation and joint development}

Modern education evaluation pays much attention to the diversification of the main body, and the content and index of evaluation need to be involved in the. In order to make the evaluation subject more reasonable and more comprehensive, we need to ensure that the main body of the evaluation is not a single form of teachers. Because teachers, experts, students and parents are associated with the teaching work, so they should participate in the teaching evaluation, to become a member of the education evaluation, so it is possible to make the participants in the teaching process more actively and initiatively. At present, in our institute by using of teaching evaluation system is experts, teachers, and the relevant departments after full discussion and research to develop out of, it not only reference and learning the other colleges and universities use the student assessment education system, together with the actual situation of our school and students reference advice, making the teaching assessment system more rational and comprehensive.

\section{Continuous optimization and improvement}

Teaching evaluation index is mainly according to the now often use the factor analysis method and design of, application oriented principle, give full consideration to the characteristics of higher vocational college students, closely around the comprehensive, accurate and objective principle, from the perspective of benefit of the operation and interaction between teachers and students, and from the teachers' teaching methods, teaching methods, teachers' life style, work correcting and curriculum for students of influence degree and students to master the knowledge of many aspects set nine indicators, and each has its own corresponding values. Students in the online education work was evaluated after the teaching system will give the evaluation of the students to carry out an automatic statistical score. Through continuous improvement and optimization evaluation index, evaluation index has been achieved detailed, quantitative and scientific, to avoid the empty and 
abstract; at the same time, the evaluation index of language becomes very simple and easy to understand, more in line with the cognitive level of the students, can make the Students' evaluation better.

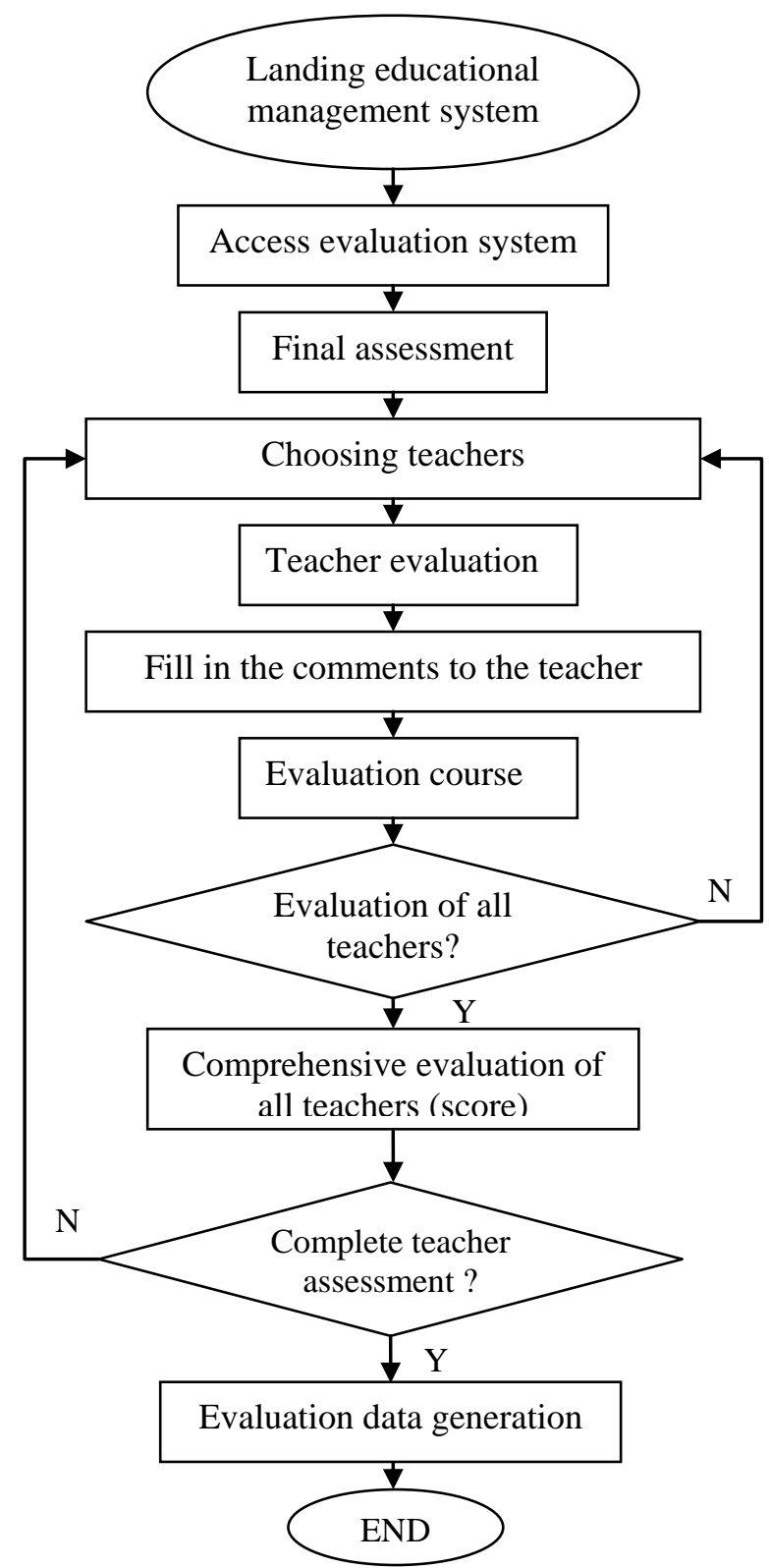

Fig. 1 The flow chart of Students' evaluation

The school management department is mainly through the students' evaluation of teaching quality, because the students' evaluation of teaching can effectively monitor the quality of teaching. Students assessment of teaching results, you can find the problems in the teaching process, so that the relevant departments to better formulate and implement methods to improve the quality of teaching. As long as colleges and universities can carefully organize students to evaluate the work, then the quality and effect of Students' evaluation will be significantly improved, but also can comprehensively and accurately get the quality of teaching information.

\section{4 evaluation data processing and analysis}

Comments processing data, you first need to clear students evaluation of teaching activities is not the purpose, but rather the judgment and evaluation of teaching quality in a way, is a means of improving teaching quality, and the implementation of Students' evaluation of teaching function and objective orientation of consistent. The processing and analysis of the students' evaluation of teaching data mainly from 3 aspects: (1) the formation of evaluation results; (2) eliminate unreasonable evaluation of teaching data; (3) all levels of data analysis. 
As Table 1,it shows the teacher classroom teaching evaluation Table to carry out the institute of Students' evaluation of teaching activities in the Wuhan Institute of Shipbuilding Technology.

Table 1 Evaluation of teacher's classroom teaching evaluation form (students' evaluation)

\begin{tabular}{|c|c|c|c|c|c|c|}
\hline \multirow{2}{*}{$\begin{array}{l}\text { First } \\
\text { level } \\
\text { index }\end{array}$} & \multirow{2}{*}{$\begin{array}{l}\text { Two } \\
\text { level } \\
\text { index }\end{array}$} & \multirow{2}{*}{ evaluation criterion } & \multicolumn{4}{|l|}{ Grade } \\
\hline & & & excell & good & comm & Poor \\
\hline \multirow{2}{*}{$\begin{array}{l}\text { teaching } \\
\text { attitude }\end{array}$} & $\begin{array}{l}\text { Imparting } \\
\text { knowledge } \\
\text { and }\end{array}$ & $\begin{array}{l}\text { Strict requirements for students concerned } \\
\text { about the students, patiently answering } \\
\text { questions, can on time after class, not }\end{array}$ & 11.4 & 10.2 & 9.0 & 7.8 \\
\hline & $\begin{array}{l}\text { Accomplis } \\
\text { hment of } \\
\text { teacher's }\end{array}$ & $\begin{array}{l}\text { Rigorous teaching style practical teaching } \\
\text { state of nature, kind, dignified and generous, } \\
\text { virtue, words and deeds }\end{array}$ & 11.4 & 10.2 & 9.0 & 7.8 \\
\hline \multirow[b]{2}{*}{$\begin{array}{l}\text { teaching } \\
\text { content }\end{array}$} & $\begin{array}{l}\begin{array}{l}\text { Teaching } \\
\text { objectives }\end{array} \\
\end{array}$ & $\begin{array}{l}\text { Teaching objectives are clear, detailed } \\
\text { and appropriate, theory with practice, the } \\
\text { system is strong }\end{array}$ & 9.5 & 8.5 & 7.5 & 6.5 \\
\hline & $\begin{array}{r}\text { Content } \\
\text { informatio } \\
n\end{array}$ & $\begin{array}{l}\text { Great amount of information, pay attention } \\
\text { to enrich and update the teaching content, } \\
\text { introducing the new theory, new technology, } \\
\text { new methods and other achievements. }\end{array}$ & 11.4 & 10.2 & 9.0 & 7.8 \\
\hline \multirow{3}{*}{$\begin{array}{l}\text { teaching } \\
\text { method }\end{array}$} & $\begin{array}{l}\text { Teacher } \\
\text { skills }\end{array}$ & $\begin{array}{l}\text { Language level clear, well structured, } \\
\text { teaching speed is moderate, neat and clear } \\
\text { writing on the blackboard }\end{array}$ & 9.5 & 8.5 & 7.5 & 6.5 \\
\hline & \begin{tabular}{|l|} 
Teaching \\
organizati \\
on
\end{tabular} & $\begin{array}{l}\text { Effective teaching design and classroom } \\
\text { management, time management, focus on } \\
\text { inspiration }\end{array}$ & 11.4 & 10.2 & 9.0 & 7.8 \\
\hline & $\begin{array}{l}\text { Teaching } \\
\text { art }\end{array}$ & $\begin{array}{l}\text { Pay attention to the teaching process of } \\
\text { teacher-student interaction, teaching process } \\
\text { design, full preparation, there is a suitable } \\
\text { way, flexible teaching methods }\end{array}$ & 9.5 & 8.5 & 7.5 & 6.5 \\
\hline \multirow{2}{*}{$\begin{array}{r}\text { teaching } \\
\text { effect }\end{array}$} & $\begin{array}{l}\text { Homewor } \\
\mathrm{k} \\
\text { correcting }\end{array}$ & $\begin{array}{l}\text { Clear requirements, selection of exercises, } \\
\text { moderate difficulty, careful of correcting } \\
\text { homework, and serious comment }\end{array}$ & 9.5 & 8.5 & 7.5 & 6.5 \\
\hline & \begin{tabular}{|l|} 
Classroom \\
effect
\end{tabular} & $\begin{array}{l}\text { It can attract the attention of students, adjust } \\
\text { the classroom atmosphere in time, teaching } \\
\text { content is impressive, understanding and }\end{array}$ & 11.4 & 10.2 & 9.0 & 7.8 \\
\hline
\end{tabular}

The data mining software CLEMENTINEA on the teaching evaluation data for statistical analysis, obtained the evaluation results show that, the students are more concerned with ethics, teaching organization, teaching effect in the classroom, content information factors, teaching skills, teaching education, teaching art, homework correcting is significant to little effect. In the evaluation of the factors of teaching and learning, students think the most important, followed by the teaching organization, the content of the information, the last is the teacher's moral accomplishment. Evaluation results showed that $72.3 \%$ of the students think whether can attract students' attention, timely adjust the classroom atmosphere will affect the scoring, 52.3\% of the students will impact score; $45.8 \%$ of the students think that a large amount of information, whether or not to pay attention to enrich and update the teaching content will affect the scoring. In addition, $37.6 \%$ of the students think whether the effective teaching design and classroom management will affect the scoring. After statistical processing, the characteristics of teachers and teachers are evaluated, as shown in Table 2 and Table 3.

Table 2 important qualities of teachers (Students' evaluation)

\begin{tabular}{|c|c|c|c|}
\hline $\begin{array}{l}\text { Teacher's } \\
\text { morality }\end{array}$ & $\begin{array}{l}\text { Teaching } \\
\text { organization }\end{array}$ & $\begin{array}{l}\text { Classroom } \\
\text { effect }\end{array}$ & $\begin{array}{l}\text { Content } \\
\text { information }\end{array}$ \\
\hline $72.3 \%$ & $52.3 \% \%$ & $45.8 \%$ & $37.6 \%$ \\
\hline
\end{tabular}


Table 3 the characteristics of teachers' important qualities (evaluation)

\begin{tabular}{|c|l|c|l|l|}
\hline Teacher skills & $\begin{array}{l}\text { Imparting } \\
\text { knowledge and } \\
\text { educating } \\
\text { people }\end{array}$ & Teaching art & $\begin{array}{l}\text { Homework } \\
\text { correcting }\end{array}$ & $\begin{array}{l}\text { The course is } \\
\text { difficult,do not } \\
\text { understand }\end{array}$ \\
\hline $78.9 \%$ & $73.4 \%$ & $58.1 \%$ & $53.8 \%$ & $40.6 \%$ \\
\hline
\end{tabular}

From poor teacher assessment of important quality characteristics show that students' evaluation of teaching activities, mainly from the learning effect as a criterion, recognition from teachers teachers in a high degree of general ethics is relatively high, teachers to teach wind preciseness, state cordial nature, dignified and generous, teacher is the most important; followed by strong organizational skills of teaching, effective teaching design and classroom management, reasonable arrangement of time, pay attention to inspire more important; then is the classroom effect, can attract the attention of students, timely adjust the classroom atmosphere is more important. Low degree of teachers (teacher assessment) the general teachers and clear language recognition, structured hierarchy, teaching speed is moderate, writing on the blackboard neat and clear is very important. In addition, demanding courses, students don't understand will have a negative impact on the teaching evaluation.

Therefore, in order to improve the teachers' self quality and teaching quality, we must first pay attention to promotion of teachers' moral cultivation; secondly, attach importance to the improvement of teachers' teaching ability. In addition, we should optimize the classroom teaching content information, teachers should pay attention to pay attention to enrich and renew the teaching content, appropriate to introduce the subject of the new theory, new technology, new methods and results; finally take diverse teachers' motivation and restraint strategy, from teachers honor and incentive wages promote teacher growth.

\section{Conclusions}

Through the evaluation of teaching data mining, it can be learned with professional morality, teaching organization of teachers and to be able to grasp the classroom effect, enrich and update teaching content of teachers,which are most popular with students, teachers. It should improve their own quality and the quality of teaching from these aspects. At the same time, these data and conclusions for the school's teaching management department to provide help for teachers' training.And it is conducive to the formation of a good quality of teacher training strategies for similar colleges and universities, which provides a reference for teacher training.

\section{Acknowledgments}

The work was supported by the the institute-level project of Wuhan Institute of Shipbuilding Technology with the project number 2016y15 and the project name Research on the Path and Method of Improving the Teaching Quality for Teachers in Higher Vocational Colleges.

\section{Reference}

[1] Zou Jingxia. Research on College Students' evaluation of teaching based on Teachers' professional development [D]. Shandong Normal University, 2009.

[2] Tan Zheng, Wang Xinxin. The evaluation index system of students' satisfaction degree of university classroom teaching construction [J]. Modern education science,2016(05):101-107.

[3] Du Juan, Huang Mei, Xu Zhenghong. From the perspective of stakeholders, Eastern China Higher Agricultural Colleges and universities public sports courses online evaluation of teaching problems and strategy research [J]. Sports science and technology, 2015(06):152-153,160.

[4] Zhang Yuemei, He Xiaoyan, Li Ziwei, Ouyang Yan. Analysis of the reasons for the evaluation of the quality of classroom teaching and the Countermeasures [J]. Journal of Yili Normal University (NATURAL SCIENCE EDITION), 2015(04):78-80. 
[5] Han Zanping, ShiGuoran. The influence factors and improvement measures of College Students' evaluation of teaching [J]. Journal of Luoyang Normal University, 2009, 28 (2): 132-135.

[6] Li Ming. The construction and application of the evaluation system of classroom teaching quality in colleges and universities [D]. North China Electric Power University (Baoding), 2009.

[7] MengFan, Wang Yuanwei, Huang Qiaoli. Study on the factors influencing college students' evaluation of teaching results in China: Based on the investigation of $\mathrm{H}$ University [J]. Education Development Research, 2014 (03): 30-35.

[8] Zhao Jia, Tian Hongmin, Lv Li. An empirical analysis on the influencing factors of the students' evaluation of teaching in Applied Undergraduate Colleges [J]. Journal of Nanchang Institute of Technology, 2015(06):69-72,76.

[9] Li Gan. The construction of teaching quality evaluation system of higher vocational college teachers to explore the [J]. Education and Teaching Forum, 2016(23):230-231.

[10] Liu Xiangxin. Analysis of the influence factors of Vocational College Students' evaluation of teaching based on partial correlation analysis [J]. Modern Economic Information, 2015(23):392-394.

[11] Cui Xu. Teaching quality supervision system in Institutions of higher art reform and innovation of [J]. Mass Art, 2015(23):215.

[12] Lin Shui. Application of fuzzy comprehensive evaluation method in students' evaluation of teaching: taking Xiamen Huatian International Vocational Institute as an example [J]. Journal of Chongqing College of Electronic Engineering, 2015(01):115-117.

[13] Zhang Yunxia. Effectiveness, problems and Countermeasures of teaching quality evaluation of college teachers [J].Teaching and Learning: Higher Education Forum, 2012 (6): 48-49.

[14] Zhao Jia, Tian Hongmin, Lv Li. An empirical analysis on the influencing factors of the students' evaluation of teaching in Applied Undergraduate Colleges [J]. Journal of Nanchang Institute of Technology, 2015(06):69-72,76. 